\title{
Pengaruh Laba Bersih dan Arus Kas Operasi Terhadap Kebijakan Dividen Pada Perusahaan Sub Sektor Perbankan Yang Terdaftar di BEI Periode 2010-2017
}

\author{
Feronika Rosalin \\ Akuntansi, Sekolah Tinggi Ilmu Ekonomi Mulia Darma Pratama \\ e-mail: feronikacandra@ymail.com
}

\begin{abstract}
Dividend policy is one of the functions of financial management, which determines how much of the net income will be distributed as dividends and how much profit will be retained. The amount of cash flow originating from the company's operating activities is the answer, whether the company's operating activities generate enough cash flow to pay dividends or not. This research uses quantitative and qualitative data analysis methods. Based on the research results obtained by the $F$ test results (simultaneously) that it was proven that there was an influence of the independent variables (net income and operating cash flow) on the dependent variable (dividend policy), while the results of the $t$ test (partially) concluded that 1. Net income had an effect on dividend policy, 2. Operating cash flow has no effect on dividend policy.
\end{abstract}

Keywords: Net Profit, Operating Cash Flow and Dividend Policy

\begin{abstract}
ABSTRAK
Kebijakan dividen merupakan salah satu fungsi manajemen keuangan, yaitu menentukan berapa banyak dari laba bersih yang akan didistribusikan sebagai dividen dan berapa banyak laba yang akan ditahan. Jumlah arus kas yang berasal dari aktivitas operasi perusahaan merupakan jawaban, apakah kegiatan operasi perusahaan menghasilkan arus kas yang cukup untuk membayar dividen atau tidak. Penelitian ini menggunakan metode analisis data kuantitatif dan kualitatif. Berdasarkan hasil penelitian diperoleh hasil uji $F$ (secara simultan) bahwa terbukti terdapat pengaruh variabel independen (laba bersih dan arus kas operasi) terhadap variabel dependen (kebijakan dividen), sedangkan pada hasil uji t (secara parsial) diperoleh kesimpulan bahwa 1. Laba bersih berpengaruh terhadap kebijakan dividen, 2. Arus kas operasi tidak berpengaruh terhadap kebijakan dividen.
\end{abstract}

Kata Kunci : Laba Bersih, Arus Kas Operasi dan Kebijakan Dividen

\section{A. Latar Belakang}

Kegiatan investasi memang selalu jadi topik yang menarik, khususnya melakukan investasi pada saham. Berinvestasi pada saham sejatinya mirip berinvestasi pada sektor properti, misalkan sebuah rumah. Jika kemudian rumah tersebut disewakan kepada orang lain, maka imbal hasilnya berasal dari uang sewa dan kenaikan harga rumah. Maka ketika membeli saham, imbal hasilnya mengalir dari pembagian dividen tunai dan kenaikan harga saham.

Setiap tahun para pemegang saham sebuah perusahaan dalam rapat umum pemegang saham (RUPS) harus memutuskan berapa persen laba bersih perusahaan yang akan dibagikan kepada pemegang saham dan sisanya diinvestasikan kembali ke perusahaan sebagai tambahan modal, yang digunakan untuk mendorong pertumbuhan perusahaan. Investasi pada hakikatnya merupakan penempatan sejumlah dana pada saat ini dengan harapan untuk memperoleh keuntungan di masa mendatang (Fahmi, 2015:2). 
Dividen menurut Rodoni dan Ali (2014:115) adalah keuntungan perusahaan yang berbentuk perseroan terbatas yang diberikan kepada para pemegang saham. Besarnya dividen yang diberikan ditentukan dalam rapat pemegang saham dan dinyatakan dalam suatu jumlah atau persentase tertentu atas nilai nominal saham dan bukan atas nilai pasarnya.

Kebijakan dividen merupakan salah satu fungsi manajemen keuangan yaitu menentukan berapa banyak dari laba bersih yaitu, selisih pendapatan dengan biaya dan pajak atas laba kena pajak yang akan didistribusikan sebagai dividen dan berapa banyak laba yang akan ditahan (Sitanggang, 2013:181). Umumnya kita berpikiran bahwa laba bersih merupakan faktor yang utama dalam kebijakan dividen, dimana perusahaan yang menghasilkan laba bersih yang besar akan membagikan dividen yang besar pula. Menurut Brigham dan Houston (2011:225) arus kas (ketersediaan kas) merupakan faktor yang juga penting. Jumlah arus kas yang berasal dari aktivitas operasi perusahaan merupakan jawaban apakah kegiatan operasi perusahaan dapat menghasilkan arus kas yang cukup untuk membayar dividen.

Faktor yang memengaruhi kebijakan dividen antara lain : Posisi kas perusahaan, batasan kreditor, aturan penurunan nilai modal, batasan saham preferen, tingkat pertumbuhan perusahaan, perbedaan pajak dan kendali perusahaan. Khusus pada posisi kas perusahaan, laba bersih yang diperoleh perusahaan tidak sama dengan jumlah kas perusahaan yang tersedia. Karena laba bersih tersebar pada aktiva perusahaan baik dalam aktiva tidak lancar maupun aktiva lancar termasuk dalam kas. Ketersediaan kas yang benar-benar bebas digunakan untuk didistribusikan sebagai dividen tergantung pada kemampuan perusahaan untuk mencairkan aktiva lancar berupa piutang dan persediaan menjadi kas setelah memperhitungkan kebutuhan kas untuk mendukung operasi perusahaan (Sitanggang, 2013:189-191).

Penelitian ini dilakukan pada sub sektor perbankan yang terdaftar di bursa efek Indonesia periode 2010-2017. Terdapat 43 perusahaan yang terdaftar di sub sektor perbankan bursa efek Indonesia. Dalam penelitian ini penulis hanya mengambil 4 (empat) perusahaan perbankan sebagai sampel penelitian, karena penulis tertarik untuk meneliti pada bank yang sebagian atau seluruh sahamnya dimiliki oleh Pemerintah Republik Indonesia (persero). Selain rutin membagikan dividen, bankbank persero juga merupakan bank dengan total asset terbesar di Indonesia (kontan.co.id).

Dari uraian latar belakang masalah di atas, maka penulis tertarik untuk mengambil judul penelitian "Pengaruh Laba Bersih Dan Arus Kas Operasi Terhadap Kebijakan Dividen Pada Perusahaan Sub Sektor Perbankan Yang Terdaftar Di Bursa Efek Indonesia Periode 2010-2017".

\section{B. Kajian Teori}

\section{Pengertian Kebijakan Dividen}

Kebijakan perusahaan membagikan dividen kepada para investor adalah kebijakan yang sangat penting. Kebijakan pembagian dividen (dividend policy) tidak saja membagikan keuntungan yang diperoleh perusahaan kepada para investor tetapi harus selalu diikuti dengan pertimbangan adanya kesempatan investasi kembali (reinvesment). Apabila dividen dibayarkan secara tunai makin meningkat, maka semakin sedikit dana yang tersedia untuk reinvestasi. Hal ini akan 
menyebabkan tingkat pertumbuhan dimasa mendatang menjadi rendah, sehingga akan menekan harga saham (Rodoni dan Ali, 2014:116).

Perusahaan yang berhasil akan mendapatkan laba. Laba tersebut kemudian dapat diinvestasikan kembali ke dalam aset operasi, digunakan untuk melunasi hutang, atau didistribusikan kepada pemegang saham. jika keputusan yang diambil adalah mendistribusikan laba kepada pemegang saham, maka akan timbul tiga permasalahan : (1) Berapa besar jumlah yang sebaiknya didistribusikan? (2) Apakah sebaiknya distribusi ini dalam bentuk dividen atau kas diserahkan kepada pemegang saham melalui pembelian saham kembali? (3) sebaiknya seberapa stabilkah distribusi tersebut; yaitu, apakah dana yang dibayarkan dari tahun ke tahun akan stabil dapat diandalkan, tentunya akan disukai oleh para pemegang saham, atau diperbolehkan bervariasi sesuai dengan arus kas perusahaan dan persyaratan investasi, yang mungkin lebih baik jika dilihat dari sudut pandang perusahaan? (Brigham dan Houston, 2011:210).

Menurut Sitanggang (2013:189) kebijakan dividen merupakan salah satu fungsi pokok manajemen keuangan yaitu menentukan besarnya laba bersih yang akan didistribusikan kepada pemegang saham yang diukur dengan DPR (dividen payout ratio).

\section{Pengertian Laba Bersih}

Laba bersih menurut Brigham dan Houston (2010:93) merupakan penjualan bersih dikurang biaya operasi, bunga dan pajak sehingga mendapatkan laba bersih. Sedangkan menurut Sitanggang (2013:181), laba bersih merupakan selisih pendapatan dengan biaya dan pajak atas laba kena pajak. Laba bersih merupakan tambahan kekayaan pemegang saham yang dapat dibagikan kepada pemegang saham atau ditahan dalam perusahaan untuk diinvestasikan kembali sebagai sumber pendanaan internal.

\section{Pengertian Arus Kas Operasi}

Arus kas merupakan aliran masuk dan keluarnya akun kas suatu perusahaan. sebagaimana yang tercantum dalam laporan arus kas untuk mengetahui penggunaan kas suatu perusahaan. keluar-masuknya kas akan memberikan pengaruh terhadap akun-akun lainnya sehingga laporan ini dianggap merupakan laporan keuangan yang lebih akurat menggambarkan kondisi perusahan yang sebenarnya (Rodoni dan Ali, 2014:18).

Arus kas yang paling utama dari perusahaan adalah terkait dengan aktivitas operasi. Aktivitas operasi meliputi transaksi-transaksi yang tergolong sebagai penentu besarnya laba/rugi bersih. Penerimaan kas dari penjualan barang atau pemberian jasa merupakan sumber arus kas masuk yang utama. Penerimaan kas lainnya berasal dari pendapatan bunga, dividen dan sebagainya. Sedangkan arus keluar meliputi pembayaran untuk membeli barang dagangan, membayar gaji/upah, beban pajak, bunga, beban utilitas, sewa dan sebagainya (Hery, 2012:205).

\section{Faktor-faktor yang Mempengaruhi Kebijakan Dividen}

Beberapa faktor yang mempengaruhi penetapan kebijakan dividen pada perusahaan sebagai berikut (Rodoni dan Ali, 2014:116):

1. Peraturan hukum. Terdapat tiga hal yang ditekankan berkaitan dengan pembayaran dividen yaitu : 
a. Peraturan mengenai laba bersih, yaitu menentukan bahwa dividen dapat dibayar dari laba dahulu dan laba sekarang.

b. Peraturan mengenai tindakan yang merugikan pemodal. Peraturan tersebut akan melindungi para kreditur, caranya dengan melarang pembayaran dividen dari dana modal yang berarti membagikan investasinya bukan membagikan keuntungan.

c. Peraturan mengenai hak mampu bayar (insolvency), yaitu menentukan bahwa perusahaan tidak membayar dividen jika tidak mampu (perusahaan bangkrut).

2. Posisi likuiditas, yaitu apabila laba ditahan telah diinvestasikan dalam bentuk aktiva tetap, seperti mesin dan peralatan, bahan dan persediaan dan barangbarang lainnya, dan bukan disimpan dalam bentuk uang tunai, maka hal tersebut dapat menunjukkan posisi likuiditas perusahaan yang rendah dan terdapat kemungkinan perusahaan tidak mampu lagi membayarkan dividennya.

3. Perlunya membayar kembali pinjaman. Disini perusahaan perlu menyisihkan laba sebelum jatuh tempo utang, agar keuntungan perusahaan pada saat jatuh temponya utang dibebani dengan pembayaran seluruh utang.

4. Keterbatasan karena kontrak uang. Dalam perjanjian utang terdapat laranganlarangan bagi debitur sehubungan dengan pembayaran dividen. Hal ini dilakukan untuk melindungi pihak kreditur sehubungan dengan dana yang dipinjamkan. Pembatasan tersebut dilakukan dengan cara dividen yang akan datang hanya boleh dibayar dari keuntungan yang diperoleh sesudah ditandatanganinya kontrak utang, atau dividen tidak dibayarkan jika modal kerja bersih jumlahnya lebih kecil dari suatu jumlah tertentu.

5. Tingkat perluasan perusahaan. Semakin cepat tingkat pertumbuhan perusahaan semakin besar kebutuhannya untuk membiayai pengembangan harta perusahaan tersebut, dan semakin banyak dana yang dibutuhkan di kemudian hari, semakin banyak pula keuntungan yang harus ditahan dan bukan untuk dibayarkan kepada pemegang saham dalam bentuk dividen (dividen relatif kecil).

6. Tingkat keuntungan (tingkat hasil pengembalian atas aktiva yang diharapkan). Hal ini menentukan perusahaan untuk membayar dividen atau menggunakannya didalam perusahaan.

7. Stabilitas perusahaan. perusahaan yang keuntungannya relatif stabil dapat memperkirakan bagaimana keuntungan dimasa depan, sehingga kemungkinan besar perusahaan akan membagikan keuntungannya dalam persentase yang lebih besar dibandingkan dengan perusahaan yang keuntungannya berfluktuasi.

8. Kemampuan memasuki pasar modal. Perusahaan besar yang sudah mempunyai profitabilitas yang tinggi dan keuntungan yang stabil akan lebih mudah memasuki pasar modal atau memperoleh dana dari luar untuk pembiayaannya. Karena itu perusahaan yang sudah mantap akan mempunyai tingkat dividen yang lebih tinggi dibanding dengan perusahaan kecil atau masih baru.

9. Kontrol. Kekhawatiran berkurangnya kekuasaan kelompok dominan dalam mengendalikan perusahaan cenderung mendorong perusahaan untuk memperbesar laba ditahan demi keperluan ekspansinya, yang berarti akan memperkecil pembayaran dividennya.

10. Kedudukan pajak para pemegang saham. pada umumnya para pemilik perusahaan yang memegang sebagian besar sahamnya tergolong kelompok berpendapatan tinggi dan merupakan pembayar pajak yang tinggi, sehingga menyebabkan perusahaan akan membayar dividen yang rendah. 
11. Pajak atas penghasilan yang diperoleh dengan tidak wajar. Seringkali perusahaan menahan keuntungan hanya untuk menghindari tarif pajak perusahaan yang tinggi, maka dikeluarkan peraturan yang membebani pajak tambahan terhadap keuntungan atas penghasilan yang diperoleh dengan tidak wajar.

Tingkat inflasi. Kecenderungan kenaikan harga termasuk harga aktiva tetap menyebabkan akumulasi penyusutan tidak lagi mencukupi untuk mengganti aktiva tetap. Oleh karena itu, perusahaan memperbesar porsi laba ditahan sehingga porsi untuk dividen menjadi berkurang.

\section{Metode Penelitian}

1. Objek Penelitian

Objek penelitian ini adalah laba bersih, arus kas operasi dan kebijakan dividen pada perusahaan sub sektor perbankan yang terdaftar di Bursa Efek Indonesia periode 2010-2017.

\section{Sumber Data}

Seluruh data yang digunakan dalam penelitian ini adalah data sekunder, yaitu data yang dikumpulkan oleh pihak lain dan telah dipublikasikan. Sebagian besar data yang digunakan dalam penelitian ini merupakan data sekunder yang diperoleh melalui situs resmi Bursa Efek Indonesia.

\section{Metode Pengumpulan Data}

Metode pengumpulan data yang digunakan dalam penelitian ini adalah studi kepustakaan (liberary search) yaitu peneliti meneliti dengan mengumpulkan data melalui internet, buku-buku pedoman dan sebagainya yang berhubungan dengan masalah yang akan dianalisis.

Metode yang digunakan dalam penelitian ini adalah metode penelitian asosiatif. Metode penelitian asosiatif adalah penelitian yang bertujuan untuk mengetahui pengaruh ataupun juga hubungan antara dua variabel atau lebih.

\section{Populasi dan Sampel}

1) Populasi

Populasi diartikan sebagai wilayah generalisasi yang terdiri atas obyek/subyek yang mempunyai kualitas dan karakteristik tertentu yang ditetapkan oleh peneliti untuk dipelajari dan kemudian ditarik kesimpulannya (Sugiyono, 2010:115). Dalam penelitian ini populasi perusahaan yang menjadi obyek penelitian yaitu perusahaan yang ada di sektor perbankan yang terdaftar di BEI periode 2010-2017 berjumlah 43 perusahaan.

\section{2) Sampel}

Dalam penelitian ini penulis hanya mengambil sebanyak 4 bank sebagai sampel penelitian dengan menggunakan metode purposive sampling yaitu teknik penentuan sampel dengan pertimbangan tertentu (Sugiyono, 2010:122). Dengan menetapkan ciri yang sesuai dengan tujuan dan kriteria-kriteria tertentu sebagai berikut :

- Bank yang dipilih adalah bank yang sebagian atau seluruh sahamnya dimiliki oleh Pemerintah Republik Indonesia (Persero). 
- Bank yang dipilih rutin membagikan dividen periode 2010-2017.

- Bank yang dipilih memiliki cabang di seluruh Indonesia.

Nama perusahaan perbankan yang dijadikan sampel penelitian ini dapat dilihat pada tabel 1 dibawah ini :

Tabel 1

Nama Perusahaan Sektor Perbankan yang Terdaftar Di Bursa Efek Indonesia sebagai Sampel Penelitian

\begin{tabular}{|c|l|}
\hline No & \multicolumn{1}{|c|}{ Nama Perusahaan } \\
\hline 1. & Bank Negara Indonesia (Persero) Tbk \\
2. & Bank Rakyat Indonesia (Persero) Tbk \\
3. & Bank Tabungan Negara (Persero) Tbk \\
4. & Bank Mandiri (Persero) Tbk \\
\hline
\end{tabular}

Sumber : www.sahamok.com (data diolah)

\section{E. Teknik Analisis Data}

Metode analisis yang digunakan dalam penelitian ini adalah :

\section{1) Metode Kuantitatif}

Metode kuantitatif yaitu suatu metode penelitian yang menganalisis dengan menggunakan perhitungan angka-angka sebagai dasar bahan pertimbangan dan memecahkan masalah dan analisis. Sebelum melakukan pengujian hipotesis dilakukan uji asumsi klasik.

Adapun langkah-langkah metode analisis kuantitatif dalam penelitian ini sebagai berikut :

a. Untuk membahas permasalahan pertama atau menguji hipotesis pertama dilakukan langkah-langkah sebagai berikut :

1. Membuat model hubungan antara variabel independen (laba bersih dan arus kas operasi) dengan variabel dependen (kebijakan dividen), sebagai berikut (Priyatno, 2014: 160) :

$$
Y^{\prime}=\mathbf{a}+\mathbf{b}_{1} \mathbf{X}_{1}+\mathbf{b}_{2} \mathbf{X}_{2}
$$

Dimana :

$Y$ : Kebijakan Dividen ,

diukur dengan rumus :

Dividen Payout Ratio $=\frac{\text { DIVIDEN KAS }}{\text { LABA BERSIH }}$

Sumber : Sitanggang (2013:182)

a : Konstanta

$b_{1} b_{2}$ : Koefisien korelasi dari variabel

$X_{1}$ dan $X_{2}$

$X_{1} \quad$ : Laba Bersih, diukur dengan

rumus:

Laba bersih $=$ penjualan bersih $-($ biaya operasi + bunga + pajak $)$

Sumber : Brigham dan Houston (2010:93)

$X_{2} \quad$ : Arus Kas Operasi, diukur dengan

rumus : 
Arus Kas Operasi $=$ Kas masuk dari kegiatan operasi - kas keluar dari kegiatan operasi - Setara kas dari kegiatan operasi

Sumber : Manurung (2009:72)

2. Merumuskan hipotesis, dapat dirumuskan sebagai berikut:

$H_{0}: b_{1}, b_{2},=0$ : Artinya diduga tidak terdapat pengaruh secara simultan variabel independen (laba bersih dan arus kas operasi) terhadap variabel dependen (kebijakan dividen).

$H_{a}: b_{1}, b_{2}, \neq 0:$ Artinya diduga terdapat pengaruh secara simultan variabel independen (laba bersih dan arus kas operasi) terhadap variabel dependen (kebijakan dividen).

3. Koefisien Determinasi $\left(R^{2}\right)$

Dalam penelitian ini $\mathrm{R}$ square $\left(R^{2}\right)$ atau adjusted $\mathrm{R}$ square ( $\mathrm{R}$ square yang telah disesuaikan), menunjukan sumbangan pengaruh variabel independen. Adjusted $\mathrm{R}$ square biasanya digunakan untuk mengukur sumbangan pengaruh jika dalam regresi menggunakan lebih dari dua variabel independen terhadap variabel dependen (Priyatno, 2014:142).

4. Melakukan uji F (Simultan)

Uji $F$ dilakukan untuk menguji signifikansi pengaruh koefisien dan variabel bebas (laba bersih dan arus kas operasi) secara bersama-sama terhadap variabel terikat (kebijakan dividen) yang diteliti. Untuk mempermudah peneliti dalam perhitungan dan sekaligus agar mendapatkan hasil yang akurat untuk pengujian hipotesis secara serentak ini, penulis menggunakan bantuan SPSS 22.0 for windows.

5. Membandingkan $F_{\text {hitung }}$ dengan $F_{\text {tabel }}$ adalah sebagai berikut:

Jika $F_{\text {hitung }}$ lebih besar dari pada $F_{\text {tabel }}$ maka terdapat pengaruh antara variabel bebas terhadap kebijakan dividen. Jika $F_{\text {hitung }}$ lebih kecil dari pada $F_{\text {tabel }}$ maka tidak terdapat pengaruh antara variabel bebas terhadap kebijakan dividen.

6. Kriteria pengujian

Jika $F_{\text {hitung }}<F_{\text {tabel }}$ maka $H_{0}$ diterima.

Jika $F_{\text {hitung }}>F_{\text {tabel }}$ maka $H_{0}$ ditolak.

Berdasarkan signifikansi:

Jika signifikansi $>0,05$ maka $H_{0}$ diterima

Jika signifikansi $<0,05$ maka $H_{0}$ ditolak

b. Untuk membahas permasalahan kedua atau menguji hipotesis kedua dilakukan langkah-langkah sebagai berikut:

1. Merumuskan hipotesis, dapat dirumuskan sebagai berikut:

$H_{0}: b_{1}, b_{2},=0$ : Artinya diduga secara parsial tidak terdapat pengaruh signifikan antara laba bersih dan arus kas operasi terhadap kebijakan dividen.

$H_{a}: b_{1}, b_{2}, \neq 0$ : Artinya diduga secara parsial terdapat pengaruh signifikan antara laba bersih dan arus kas operasi terhadap kebijakan dividen. 
2. Melakukan uji t (Parsial)

Uji t dilakukan untuk menguji signifikansi pengaruh koefisien dan variabel bebas (laba bersih dan arus kas operasi) secara parsial terhadap variabel terikat (kebijakan dividen) yang diteliti. Untuk mempermudah peneliti dalam perhitungan dan sekaligus agar mendapatkan hasil yang akurat untuk pengujian hipotesis secara serentak ini, penulis menggunakan bantuan SPSS 22.0 for windows.

3. Membandingkan $t_{\text {hitung }}$ dan $t_{\text {tabel }}$ adalah sebagai berikut:

Jika $t_{\text {hitung }}$ lebih besar dari pada $t_{\text {tabel }}$ maka terdapat pengaruh antara variabel bebas terhadap kebijakan dividen. Jika $t_{\text {hitung }}$ lebih kecil dari pada $t_{\text {tabel }}$ maka tidak terdapat pengaruh antara variabel bebas terhadap kebijakan dividen.

4. Kriteria pengujian

$H_{0}$ diterima jika $-t_{1 / 2 a} \leq t_{\text {hitung }} \leq t_{1 / 2 a}$

$H_{0}$ ditolak jika $t_{\text {hitung }} \leq-t_{1 / 2 a}$ atau $\leq t_{1 / 2 a}$

Berdasarkan signifikansi:

Jika signifikansi $>0,05$ maka $H_{0}$ diterima

Jika signifikansi $<0,05$ maka $H_{0}$ ditolak

\section{2) Metode Kualitatif}

Metode kualitatif yaitu suatu metode yang dimulai dengan cara mengumpulkan data, mencatat data, mengklasifikasikan data dan menganalisis data berdasarkan permasalahan yang telah dirumuskan dan kemudian menarik kesimpulan. Dalam penelitian ini akan dianalisa secara objektif dan terarah mengenai pengaruh laba bersih dan arus kas operasi terhadap kebijakan dividen yang telah dianalisa dengan menggunakan metode kuantitatif.

F. Hasil dan Pembahasan

1. Perkembangan Laba Bersih Pada Perusahaan Sub Sektor Perbankan yang Terdaftar Di BEI Periode 2010-2017

Tabel 2

Laba Bersih Perusahaan Sub Sektor Perbankan yang Terdaftar Di BEI Periode 2010-2017

(dalam jutaan rupiah)

\begin{tabular}{|c|c|c|c|c|c|c|c|c|}
\hline \multirow{2}{*}{ Tahun } & \multicolumn{2}{|c|}{ BBNI } & \multicolumn{2}{c|}{ BBRI } & \multicolumn{2}{c|}{ BBTN } & \multicolumn{2}{c|}{ BMRI } \\
\cline { 2 - 8 } & Absolut & Persentase & Absolut & Persentase & Absolut & Persentase & Absolut & Persentase \\
\hline 2010 & 4.101 .706 & - & 11.472 .385 & - & 915.938 & - & 9.218 .298 & - \\
\hline 2011 & 5.808 .218 & 41,60 & 15.087 .996 & 31,52 & 1.118 .661 & 22,13 & 12.246 .044 & 32,84 \\
\hline 2012 & 7.048 .362 & 21,35 & 18.687 .380 & 23,86 & 1.363 .962 & 21,93 & 15.504 .067 & 26,60 \\
\hline 2013 & 9.057 .941 & 28,51 & 21.354 .330 & 14,27 & 1.562 .161 & 14,53 & 18.203 .753 & 17,41 \\
\hline 2014 & 10.829 .379 & 19,56 & 24.253 .845 & 13,58 & 1.115 .592 & $-28,59$ & 19.871 .873 & 9,16 \\
\hline 2015 & 9.140 .532 & $-15,60$ & 25.410 .788 & 4,77 & 1.850 .907 & 65,91 & 20.334 .968 & 2,33 \\
\hline 2016 & 11.410 .196 & 24,83 & 26.227 .991 & 3,22 & 2.618 .905 & 41,49 & 13.806 .565 & $-32,10$ \\
\hline 2017 & 13.770 .592 & 20,69 & 29.044 .334 & 10,74 & 3.027 .466 & 15,60 & 20.639 .683 & 49,49 \\
\hline Rata-Rata & 8.895 .866 & 20,14 & 21.442 .381 & 14,56 & 1.696 .699 & 21,86 & 16.228 .156 & 15,11 \\
\hline
\end{tabular}

Sumber : Laporan keuangan perusahaan tercatat di BEl (data diolah, 2018) 


\section{Perkembangan Arus Kas Operasi Pada Perusahaan Sub Sektor Perbankan yang Terdaftar Di BEI Periode 2010-2017}

Tabel 3

\section{Arus Kas Operasi Perusahaan Sub Sektor Perbankan yang Terdaftar Di BEI Periode 2010-2017}

(dalam jutaan rupiah)

\begin{tabular}{|c|c|c|c|c|c|c|c|c|}
\hline \multirow{2}{*}{ Tahun } & \multicolumn{2}{|c|}{ BBNI } & \multicolumn{2}{|c|}{ BBRI } & \multicolumn{2}{|c|}{ BBTN } & \multicolumn{2}{|c|}{ BMRI } \\
\hline & Absolut & Persentase & Absolut & Persentase & Absolut & Persentase & Absolut & Persentase \\
\hline 2010 & -14.154 .127 & - & 46.517 .667 & - & -2.832 .958 & - & 42.109 .002 & - \\
\hline 2011 & 15.384 .156 & $-208,69$ & 15.975 .074 & $-65,66$ & 4.799 .245 & $-269,41$ & 20.440 .640 & $-51,46$ \\
\hline 2012 & 6.948 .459 & $-54,83$ & 24.097 .325 & 50,84 & 1.831 .532 & $-61,84$ & 8.798 .671 & $-56,96$ \\
\hline 2013 & -5.006 .646 & $-172,05$ & 4.399 .086 & $-81,74$ & -3.295 .676 & $-279,94$ & 12.733 .517 & 44,72 \\
\hline 2014 & -610.370 & $-87,81$ & 84.930 .076 & 1830,63 & -2.049 .009 & $-37,83$ & 21.091 .691 & 65,64 \\
\hline 2015 & 24.356 .628 & $-4090,47$ & 45.544 .908 & $-46,37$ & 1.707 .579 & $-183,34$ & 8.952 .036 & $-57,56$ \\
\hline 2016 & 15.422 .131 & $-36,682$ & 21.770 .833 & $-52,20$ & 9.783 .925 & 472,97 & 41.521 .119 & 363,82 \\
\hline 2017 & 33.625 .853 & 118,04 & 39.299 .109 & 80,51 & 321.044 & $-96,72$ & 5.192 .544 & $-87,49$ \\
\hline Rata-Rata & 9.495 .761 & $-647,50$ & 35.316 .760 & 245,14 & 1.283 .210 & $-65,16$ & 20.104 .903 & 31,53 \\
\hline
\end{tabular}

Sumber : Laporan keuangan perusahaan tercatat di BEl (data diolah, 2018)

3. Perkembangan Kebijakan Dividen Pada Perusahaan Sub Sektor Perbankan yang Terdaftar Di BEI Periode 2010-2017

Tabel 4

Hasil Perhitungan Dividen Payout Ratio (DPR)

Periode 2010-2017 (dalam jutaan rupiah)

\begin{tabular}{|c|c|c|c|c|c|}
\hline No & Keterangan & Tahun & Laba Bersih & Dividen & DPR (\%) \\
\hline \multirow{8}{*}{1.} & \multirow{8}{*}{ BBNI } & 2010 & 4.101 .706 & 1.230 .512 & 30,00 \\
\hline & & 2011 & 5.808 .218 & 1.165 .181 & 20,01 \\
\hline & & 2012 & 7.048 .362 & 2.113 .844 & 30,00 \\
\hline & & 2013 & 9.057 .941 & 2.716 .304 & 30,00 \\
\hline & & 2014 & 10.829 .379 & 2.695 .654 & 24,89 \\
\hline & & 2015 & 9.140 .532 & 2.266 .885 & 24,80 \\
\hline & & 2016 & 11.410 .196 & 3.968 .562 & 34,78 \\
\hline & & 2017 & 13.770 .592 & 4.765 .767 & 34,61 \\
\hline \multirow{8}{*}{2.} & \multirow{8}{*}{ BBRI } & 2010 & 11.472 .385 & 1.727 .950 & 15,06 \\
\hline & & 2011 & 15.087 .996 & 3.016 .585 & 19,99 \\
\hline & & 2012 & 18.687 .380 & 5.556 .285 & 29,73 \\
\hline & & 2013 & 21.354 .330 & 6.348 .045 & 29,73 \\
\hline & & 2014 & 24.253 .845 & 7.273 .684 & 29,99 \\
\hline & & 2015 & 25.410 .788 & 7.619 .322 & 29,98 \\
\hline & & 2016 & 26.227.991 & 10.483 .777 & 39,97 \\
\hline & & 2017 & 29.044 .334 & 13.048 .441 & 44,92 \\
\hline \multirow{8}{*}{3.} & \multirow{8}{*}{ BBTN } & 2010 & 915.938 & 274.781 & 29,99 \\
\hline & & 2011 & 1.118 .661 & 223.732 & 19,99 \\
\hline & & 2012 & 1.363 .962 & 409.189 & 30,00 \\
\hline & & 2013 & 1.562 .161 & 468.648 & 29,99 \\
\hline & & 2014 & 1.115 .592 & 223.119 & 20,00 \\
\hline & & 2015 & 1.850 .907 & 370.181 & 19,99 \\
\hline & & 2016 & 2.618 .905 & 523.781 & 20,00 \\
\hline & & 2017 & 3.027 .466 & 605.493 & 19,99 \\
\hline 4. & BMRI & 2010 & 9.218 .298 & 2.813 .973 & 30,53 \\
\hline
\end{tabular}




\begin{tabular}{|l|l|l|l|l|}
\hline \multirow{4}{*}{} & 2011 & 12.246 .044 & 2.449 .209 & 20,00 \\
\cline { 2 - 5 } & 2012 & 15.504 .067 & 4.651 .220 & 29,99 \\
\cline { 2 - 5 } & 2013 & 18.203 .753 & 5.461 .126 & 30,00 \\
\cline { 2 - 5 } & 2014 & 19.871 .873 & 4.967 .968 & 24,99 \\
\cline { 2 - 5 } & 2015 & 20.334 .968 & 6.100 .490 & 29,99 \\
\cline { 2 - 5 } & 2016 & 13.806 .565 & 6.212 .954 & 44,99 \\
\cline { 2 - 5 } & 2017 & 20.639 .683 & 9.287 .857 & 44,99 \\
\hline & 12.065 .776 & 3.782 .516 & 28,56 \\
\hline \multicolumn{4}{|c|}{ Rata-rata } \\
Sumber : Laporan keuangan perusahaan tercatat di BEI (data diolah, 2018)
\end{tabular}

\section{Uji Normalitas Data}

Tabel 5

Hasil Pengujian Normalitas Data

One-Sample Kolmogorov-Smirnov Test

\begin{tabular}{|ll|r|}
\hline & & $\begin{array}{c}\text { Unstandardize } \\
\text { d Residual }\end{array}$ \\
\hline N & Mean & 32 \\
& &, 0000000 \\
Most Extreme Differences & Std. Deviation &, 03854684 \\
& Absolute &, 138 \\
& Positive &, 138 \\
Test Statistic & Negative &,- 058 \\
Asymp. Sig. (2-tailed) & &, 138 \\
\hline
\end{tabular}

a. Test distribution is Normal.

b. Calculated from data.

c. Lilliefors Significance Correction.

Sumber : Data diolah SPSS, 2018

\section{Gambar 1}

\section{Grafik Normal Probability-Plot}

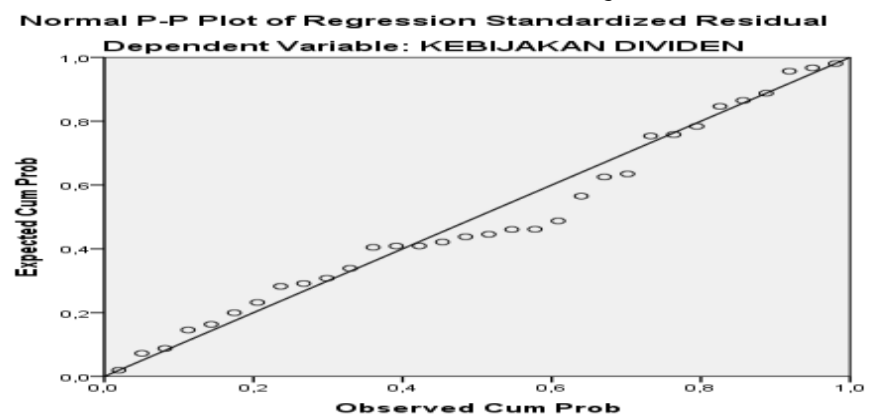

Sumber : Data diolah SPSS, 2018

\section{Uji Multikolinieritas}

\section{Tabel 6}

\section{Uji Multikolinieritas}

Coefficients $^{a}$

\begin{tabular}{|c|c|c|c|c|c|c|c|}
\hline \multirow[b]{2}{*}{ Model } & \multicolumn{2}{|c|}{$\begin{array}{l}\text { Unstandardized } \\
\text { Coefficients }\end{array}$} & \multirow{2}{*}{$\begin{array}{c}\begin{array}{c}\text { Standardized } \\
\text { Coefficients }\end{array} \\
\text { Beta }\end{array}$} & \multirow[b]{2}{*}{$\mathbf{t}$} & \multirow[b]{2}{*}{ Sig. } & \multicolumn{2}{|c|}{$\begin{array}{l}\text { Collinearity } \\
\text { Statistics }\end{array}$} \\
\hline & B & Std. Error & & & & Tolerance & VIF \\
\hline (Constant) & ,426 &, 170 & & 2,506 & ,018 & & \\
\hline LABA BERSIH & ,652 & 245 & ,515 & 2,661 & ,013 & ,735 & 1,360 \\
\hline ARUS KAS OPERASI &,- 025 & ,028 &,- 174 &,- 898 & ,376 & ,735 & 1,360 \\
\hline
\end{tabular}

a. Dependent Variable: KEBIJAKAN DIVIDEN

Sumber : Data diolah SPSS, 2018 


\section{Uji Heteroskedastisitas}

\section{Gambar 2 \\ Uji Heteroskedastisitas Corelations}

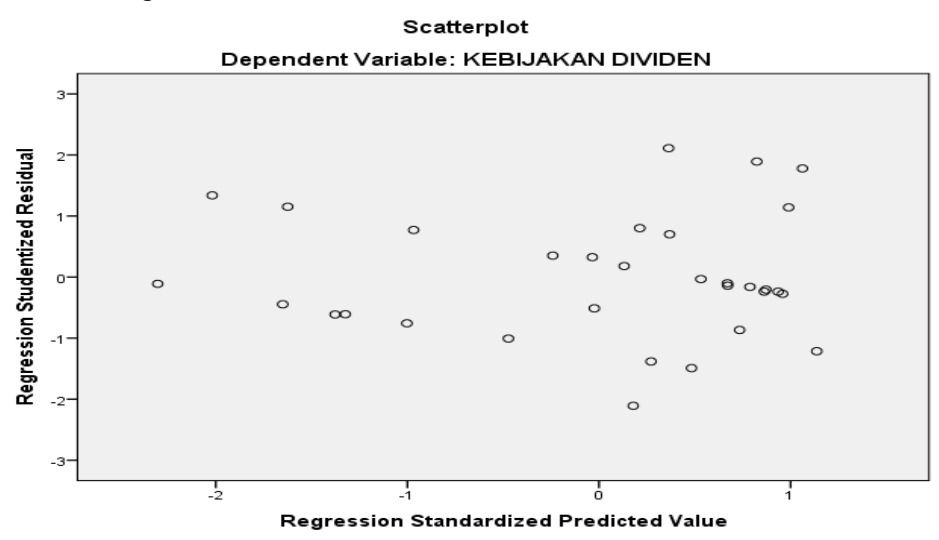

Sumber : Data diolah SPSS, 2018

\section{Uji Autokorelasi}

\section{Tabel 7}

\section{Uji Autokorelasi}

Model Summaryb

\begin{tabular}{|l|r|r|r|r|r|}
\hline Model & $\mathbf{R}$ & R Square & $\begin{array}{c}\text { Adjusted R } \\
\text { Square }\end{array}$ & $\begin{array}{c}\text { Std. Error of } \\
\text { the Estimate }\end{array}$ & Durbin-Watson \\
\hline 1 &, $451^{\mathrm{a}}$ &, 203 &, 148 &, 03985 & 1,203 \\
\hline
\end{tabular}

a. Predictors: (Constant), ARUS KAS OPERASI, LABA BERSIH

b. Dependent Variable: KEBIJAKAN DIVIDEN

Sumber : Data diolah SPSS, 2018

\section{Uji Analisis Regresi Linier Berganda}

Tabel 8

Analisis Regresi Linier Berganda

Coefficients $^{a}$

\begin{tabular}{|c|c|c|c|c|c|c|}
\hline \multirow{2}{*}{\multicolumn{2}{|c|}{ Model }} & \multicolumn{2}{|c|}{$\begin{array}{c}\text { Unstandardized } \\
\text { Coefficients }\end{array}$} & $\begin{array}{l}\text { Standardized } \\
\text { Coefficients }\end{array}$ & \multirow[t]{2}{*}{ t } & \multirow[t]{2}{*}{ Sig. } \\
\hline & & B & Std. Error & Beta & & \\
\hline \multirow[t]{3}{*}{1} & (Constant) & ,426 & , 170 & & 2,506 & ,018 \\
\hline & LABA BERSIH & 652, & 245, &, 515 & 2,661 & 013, \\
\hline & ARUS KAS OPERASI &,- 025 & ,028 &,- 174 &,- 898 & ,376 \\
\hline
\end{tabular}

a. Dependent Variable: KEBIJAKAN DIVIDEN

Sumber : Data diolah SPSS, 2018

9. Uji Koefisien Determinasi $\left(\mathbf{R}^{2}\right)$

\section{Tabel 9}

Hasil Analisis Koefisien Determinasi

Model Summary

\begin{tabular}{|l|r|r|r|r|}
\hline Model & $\mathbf{R}$ & R Square & $\begin{array}{c}\text { Adjusted R } \\
\text { Square }\end{array}$ & $\begin{array}{c}\text { Std. Error of } \\
\text { the Estimate }\end{array}$ \\
\hline 1 &, $451^{\mathrm{a}}$ &, 203 &, 148 &, 03985 \\
\hline
\end{tabular}

a. Predictors: (Constant), ARUS KAS OPERASI, LABA BERSIH

Sumber : Data diolah SPSS, 2018 


\section{Pengujian Hipotesis 1 Uji F (Anova)}

\section{Tabel 10 \\ Hasil Analisis Uji Simultan \\ ANOVA $^{\mathrm{a}}$}

\begin{tabular}{|c|c|c|c|c|c|c|}
\hline & Model & Sum of Squares & Df & Mean Square & $\mathbf{F}$ & Sig. \\
\hline \multirow[t]{3}{*}{1} & Regression & ,012 & 2 & \multirow{3}{*}{$\begin{array}{r}, 006 \\
, 002\end{array}$} & \multirow[t]{3}{*}{3,693} & \multirow[t]{3}{*}{, $037^{b}$} \\
\hline & Residual & ,046 & 29 & & & \\
\hline & Total & ,058 & 31 & & & \\
\hline
\end{tabular}

a. Dependent Variable: KEBIJAKAN DIVIDEN

b. Predictors: (Constant), ARUS KAS OPERASI, LABA BERSIH

Sumber : Data diolah SPSS, 2018

\section{Pengujian Hipotesis 2 Uji t (Koefisien)}

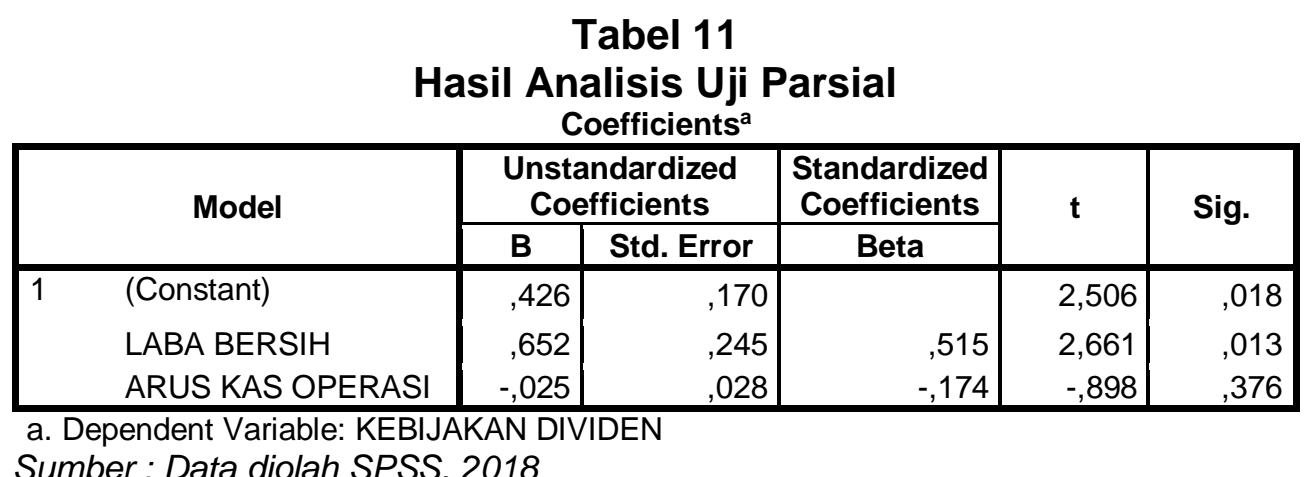

\section{G. Kesimpulan dan Saran \\ 1. Kesimpulan}

Berdasarkan hasil analisis dan pembahasan yang telah dilakukan pada bab sebelumnya, maka peneliti dapat menarik kesimpulan bahwa berdasarkan hasil pengujian antara laba bersih dan arus kas operasi terhadap kebijakan dividen (dividen payout ratio) pada periode penelitian 2010-2017 yaitu :

1. Perkembangan laba bersih diperoleh kesimpulan bahwa, rata-rata perusahaan sub sektor perbankan yang menjadi objek penelitian mengalami rata-rata peningkatan laba bersih sebesar $17,92 \%$ setiap tahunnya. Hal tersebut disebabkan karena naiknya pendapatan atau penghasilan perusahaan setiap tahunnya, salah satu faktor yang mempengaruhi laba bersih adalah naik turunnya jumlah unit barang yang dijual dan harga jual per unit dan naik turunnya pos penghasilan atau biaya operasional yang dipengaruhi oleh variasi jumlah unit yang dijual, variasi dalam tingkat harga dan kebijaksanaan dalam pemberian atau penerimaan.

2. Perkembangan arus kas operasi diperoleh kesimpulan bahwa, rata-rata perusahaan perbankan yang menjadi objek penelitian mengalami penurunan arus kas operasi sebesar $-108,20 \%$ setiap tahunnya. Hal tersebut disebabkan oleh persaingan dalam bisnis perbankan yang semakin ketat sehingga membutuhkan pengembangan dan diversifikasi produk setiap tahunnya, terutama dalam bidang teknologi. Salah satu faktor yang mempengaruhi arus kas operasi adalah pengembangan, dimana bertujuan untuk kelangsungan hidup perusahaan dimasa yang akan datang.

3. Perkembangan kebijakan dividen (dividen payout ratio) diperoleh kesimpulan bahwa rata-rata mengalami kenaikan sebesar $28,56 \%$ setiap tahunnya, hal ini 
disebabkan kenaikan laba bersih yang diikuti oleh kenaikan pembagian dividen setiap tahunnya. Salah satu faktor yang mempengaruhi kebijakan dividen yaitu tingkat keuntungan perusahaan.

4. Hasil pada penelitian ini menunjukkan bahwa nilai koefisien determinasi ( $R$ Square) adalah sebesar 0,203. Berarti bahwa kontribusi variabel bebas yaitu laba bersih dan arus kas operasi terhadap kebijakan dividen adalah sebesar $20,3 \%$ sedangkan sisanya $79,7 \%(100 \%-20,3 \%)$ dikontribusikan oleh variabel lain yang tidak diteliti dalam penelitian ini.

5. Hasil pengujian untuk menjawab rumusan masalah apakah laba bersih dan arus kas operasi berpengaruh secara simultan terhadap kebijakan dividen pada perusahaan sub sektor perbankan yang terdaftar di Bursa Efek Indonesia pada periode penelitian 2010-2017 diperoleh kesimpulan bahwa $F_{\text {hitung }}>F_{\text {tabel }}(3,693>$ $3,328)$ dan tingkat signifikan lebih kecil $0,05(0,037<0,05)$, artinya terbukti terdapat pengaruh secara simultan variabel independen (laba bersih dan arus kas operasi) terhadap variabel dependen (kebijakan dividen). Sedangkan hasil pengujian untuk menjawab rumusan masalah apakah laba bersih dan arus kas operasi berpengaruh secara parsial terhadap kebijakan dividen pada perusahaan sub sektor perbankan yang terdaftar di Bursa Efek Indonesia pada periode penelitian 2010-2017 diperoleh kesimpulan yaitu sebagai berikut:

a. Hasil perhitungan laba bersih memperlihatkan bahwa nilai thitung $>t_{\text {tabel }}$ atau $2,661>2,045$ dan signifikansi $<0,05$ atau 0,013 $<0,05$, maka $\mathrm{H}_{0}$ ditolak dan menerima $\mathrm{H}_{\mathrm{a}}$. Dengan demikian dapat ditarik kesimpulan bahwa laba bersih berpengaruh secara parsial terhadap kebijakan dividen (dividen payout ratio).

b. Hasil perhitungan arus kas operasi memperlihatkan bahwa nilai thitung $<t_{\text {tabel }}$ atau $-0,898<2,045$ dan signifikansi $>0,05$ atau 0,376 $>0,05$, maka $\mathrm{H}_{0}$ diterima dan menolak $\mathrm{H}_{\mathrm{a}}$. Dengan demikian dapat ditarik kesimpulan bahwa arus kas operasi tidak berpengaruh secara parsial terhadap kebijakan dividen (dividen payout ratio).

\section{Saran}

Berdasarkan hasil kesimpulan diatas, maka penulis dapat memberikan beberapa saran antara lain sebagai berikut :

1. Pihak Perusahaan

Hasil pengujian pada perusahaan sub sektor perbankan yang terdaftar di BEI periode 2010-2017 memperlihatkan bahwa laba bersih merupakan salah satu faktor yang utama dalam menentukan kebijakan dividen, diharapkan kemampuan menghasilkan laba bersih yang baik ini, dapat terus ditingkatkan setiap tahunnya, sehingga kedepannya kepercayaan publik terutama investor terhadap perusahaan dapat terus meningkat serta dapat menarik investor baru untuk ikut serta menanamkan modalnya di perusahaan.

2. Pihak Investor

Hasil pengujian memperlihatkan bahwa perusahaan sub sektor perbankan yang terdaftar di BEI periode 2010-2017 memiliki laba bersih yang rata-rata naik setiap tahunnya, dan walaupun arus kas operasi perusahaan mengalami fluktuasi, perusahaan secara rutin tetap membayarkan dividen bahkan cenderung naik setiap tahunnya. Berdasarkan hasil pengujian laba bersih berpengaruh positif terhadap kebijakan dividen tersebut dapat dijadikan sandaran bagi investor sebelum menanamkan modalnya pada perusahaan, untuk memperhatikan 
terlebih dahulu kemampuan perusahaan dalam menghasilkan laba bersih yang kemudian dapat dibagikan sebagai keuntungan kepada pemegang saham.

3. Penelitian Selanjutnya

Diharapkan pada penelitian selanjutnya dapat meneliti dengan menambahkan variabel lain yang tidak diteliti dalam penelitian ini antara lain : posisi likuiditas, kebutuhan pelunasan hutang, pembatasan dalam perjanjian hutang, tingkat ekspansi aktiva, kendali perusahaan dan lain-lain.

\section{DAFTAR PUSTAKA}

Brigham \& Houston. 2010. Dasar-Dasar Manajemen Keuangan Buku 1 Edisi 10. Jakarta : Salemba Empat.

Brigham \& Houston. 2011. Dasar-Dasar Manajemen Keuangan Buku 2 Edisi 11. Jakarta : Salemba Empat

Fahmi, Irham. 2015. Manajemen Investasi Edisi 2. Jakarta : Salemba Empat.

Hery. 2012. Pengantar Akuntansi II. Jakarta : Bumi Aksara.

Irawan \& Nurdhiana. 2010. Pengaruh laba bersih dan arus kas operasi terhadap kebijakan dividen pada perusahaan yang terdaftar di BEl periode 2009-2010. Semarang : Sekolah Tinggi Ilmu Ekonomi Widya Manggala.

Jumingan. 2006. Analisis Laporan Keuangan. Jakarta : Bumi Aksara.

Manurung, Indah Agustina. 2009. Pengaruh Laba Bersih Dan Arus Kas Operasi Terhadap Kebijakan Dividen Pada Perusahaan Manufaktur Yang Go Publik. Medan : Universitas Sumatera Utara.

Noviyanto, A. 2016. Pengaruh laba bersih, arus kas operasi dan likuiditas terhadap kebijakan dividen. Yogyakarta : Universitas Negeri Yogyakarta.

Priyatno, Duwi. SPSS 22 : Pengolah Data Terpraktis. Jakarta : Andi.

Rodoni, Ahmad., Ali, Herni. 2014. Manajemen Keuangan Modern. Jakarta : Mitra Wacana Media.

Sitanggang, J.P. 2013. Manajemen Keuangan Perusahaan Lanjutan. Jakarta: Mitra Wacana Media.

Sugiyono. 2010. Metode Penelitian Bisnis. Bandung: Alfabeta.

Syahrial, Dermawan., Purba, Djahotman. 2013. Analisis Laporan Keuangan Cara Mudah Dan Praktis Memahami Laporan Keuangan. Jakarta : Mitra Wacana Media

Tan \& Linuwih. 2013. Prediksi laba bersih dan arus kas operasi terhadap dividen badan usaha sektor manufaktur di BEI periode 2008-2011. Surabaya: Fakultas Bisnis Dan Ekonomika. 